\title{
The Role of Fintech Encourages the Export of Small Medium Enterprises in Indonesia
}

\author{
Ragimun ${ }^{1}$, Sri Yanthy Yosepha² \\ ${ }^{1}$ Researcher at Fiscal Policy Agency, Ministry of Finance, Republic of Indonesia \\ ${ }^{2}$ Lecturer at Economics Faculty of Dirgantara Suryadarma University in Jakarta, Indonesia \\ ragimun@gmail.com, yosepha@universitassuryadarma.ac.id
}

\begin{abstract}
At present the development of financial technology (fintech) in Indonesia is very fast, many nonbank companies practice as fintech executors who channel loans to the public or Small Medium Enterprise (SMEs), this has the potential to lead to illegal banking practices (shadow banking). The next problem is how the government makes rules that can synergize fintech with the business world, banking, SMEs and others. In the future, it is expected that Fintech will play an active role in encouraging the export of the SME sector which is Indonesia's flagship sector. In this study a qualitative descriptive approach was used, which emphasized the discussion by examining the role of fintech to encourage the export of small and medium industries in Indonesia. Data sources that can be used are data from the Central Statistics Agency (BPS), the Financial Services Authority (OJK), Bank Indonesia and various relevant data sources. Fintech is currently very helpful in helping the financial literacy of the Indonesian people including SMEs as a mainstay of increasing exports in Indonesia. Several obstacles to the spread of the role of fintech continue to be overcome through various means including infrastructure improvements, socialization and financial literacy to the public and SMEs and fintech regulatory policies. The government needs to make harmonious rules to grow and to avoid risks in the financial services industry. This is crucial because the development of fintech in Indonesia is very fast. Licensing for the establishment of fintech companies from other countries must be monitored.
\end{abstract}

Keyword: Fintech, Export Increase, SME's

\section{Introduction}

The development of fintech in Indonesia is currently very fast. However, many residents and community groups and small industries have not been fully served by information technology, as in the financial and banking industries. This is because the financial industry, especially banks, in implementing the rules is still very strict. In addition, there are limitations in the banking and non-banking industries such as market access and distribution access. On the other hand, people are looking for alternatives to use the services of the traditional financial industry by using financial technology that solves problems. Basically people or small and medium industries need alternative information, services and financing that are more democratic, transparent and more efficient. Fintech players in Indonesia are still dominated by payments that amount to 43 percent, loans 17 percent, and the rest are collectors or aggregators, crowdfunding and others. Crowdfunding is the practice of raising funds from a large number of people to capitalize on a project or business that is generally done through the internet or funding techniques for projects or business units that involve the community at large (Akbar, 2016) ${ }^{3}$. The purpose of Fintech in the financial world includes making it easier for people to access various products in the financial sector and facilitate transactions and improve financial literacy. In addition, Fintech is also a new information technology innovation that aims to replace various traditional financial services. Likewise, it can facilitate public access to these services. The

\footnotetext{
${ }^{1}$ Corresponding Author: Ragimun; Fiscal Policy Agency, Republic of Indonesia, R.M. Notohamiprodjo Building 7th floor, Jl. Dr. Wahidin no. 1 Jakarta, 10710, Tel: +62-21 3451128, Fax: +62-21 3451205, E-mail: ragimun@gmail.com ${ }^{2}$ Sri Yanthy Yosepha; Campus B Jl. Angkasa, Angkasa Complex, Halim Perdanakusuma East Jakarta Indonesia E-mail: yosepha@universitassuryadarma.ac.id
}

${ }^{3}$ Akbar D.S. Fadillah. 2016. Crowdfunding Concept for Infrastructure Funding in Indonesia. Ministry of Finance. Downloaded on 1 February 2018 at 11.33, from https://www.kemenkeu.go.id/media/4402/konsepcrowdfunding-for-pendanaan-infrastruktur-di-indonesia.pdf 
development of fintech since the 1950s since the discovery of credit cards to date by using digitized retail financing services, will be seen in the following picture Digital services like fintech not only encourage economic growth.

Figure 1: Development of Fintech (The Evolution of Financial Technology)

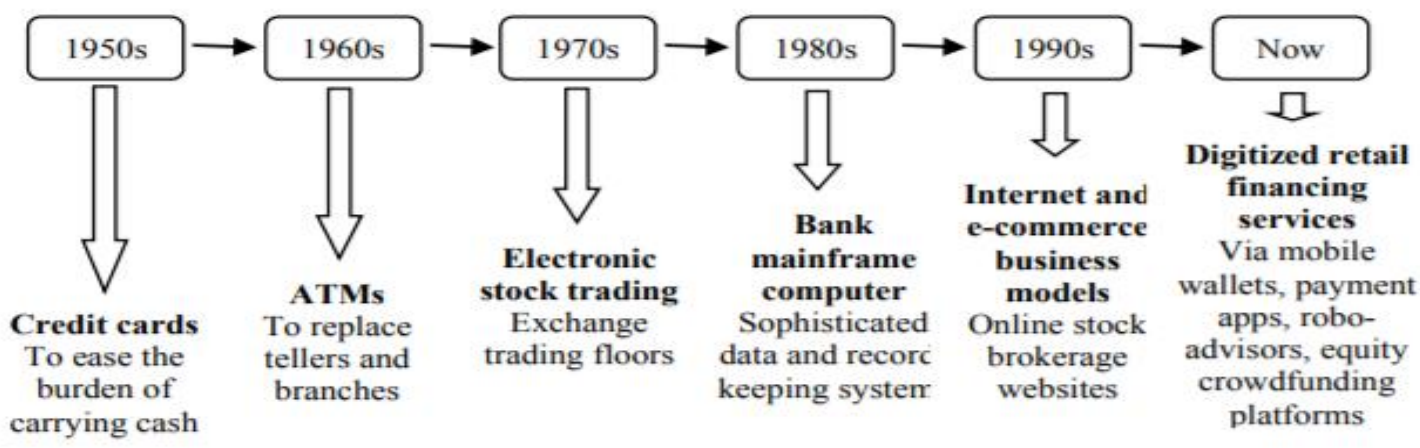

Source: Falguni Desai, $2015^{4}$

Indonesia, but also change business practices and replace traditional financing and payment methods. Research (Deloitte, 2015) ${ }^{5}$ entitled Digital Financial Services in Indonesia states that digital financial services will make access to the financial system increase so that it benefits the national economy. Meanwhile, according to the World Bank study, an increase of 1 percent in financial system facilities could increase GDP growth per capita by 0.03 percent. This economic growth then affects the growth of new jobs. The increase in financial inclusion by 20 percent through this digital service will generate 1.7 million new jobs. Increasing banking access also makes businesses, especially small and medium enterprises (SMEs), easier. New entrepreneurs are now emerging along with the ease of selling goods through the internet. Traders do not have to have a conventional stall or shop to sell their products. They can sell through various media such as social media, websites to special applications. The development of business with internet media is also supported by Indonesia's position as the largest e-commerce country in Southeast Asia.

\section{Fintech Constraints Increase Exports for SMEs In Indonesia}

Infrastructure: At present, a good IT infrastructure is only felt by people in large urban areas such as Jakarta, Surabaya, Bandung and so on. While the internet network has not evenly spread into remote areas or SMEs in the region, this is one of the biggest obstacles to the spread of fintech in Indonesia.

Human Resources: The limited ability of rural communities and SMEs in particular in applying fintech makes its distribution stunted. This condition makes it difficult for the government to develop fintech in the region's SMEs because of the lack of capable and skilled workers who can support the increase in exports of these SME products.

Regulation or Legislation: Currently the fintech industry is based on civil law, there are no specific rules regarding fintech. This has become one of the obstacles to the spread of fintech in the community. Therefore the government needs to issue regulations related to fintech so that public interest or SMEs to be able to use fintech will increase.

\footnotetext{
${ }^{4}$ Desai, Falguni. (2015). The Evolution of Fintech. https://www.forbes.com/sites/falgunidesai/ 2015/12/13/theevolution-of-fintech/\#286fcfcc7175 [online] 04 August 2017.

5 Deloitte. 2015. Digital Financial Services in Indonesia. Downloaded on March 6, 2018 at 9:56 a.m., from https://www2. Deloitte .com/content/dam/ Deloitte /sg/ Documents /financial-services /sea-fsi-digital-financials ervices-in-Indonesia- noexp .pdf
} 
Lack of Financial Literacy: Most of the people or SMEs in the countryside do not know fintech regarding the use, benefits, and objectives of using fintech because of the lack of government literacy about the financial system properly. Therefore, it is necessary to take steps to disseminate and discuss through various media including social media to get the public's attention and as an effort to seek input for the improvement of the existing system. As a result of the low level of knowledge of financial literacy, the people or SMEs do not have good financial management planning. Likewise, licensing for the establishment of Fintech companies from other countries can be monitored because there are some indications of an unlicensed fintech company operating in Indonesia.

\section{Literature Review}

In 2014, the research institute (Euromonitor) noted that online sales in Indonesia reached the US \$ 1.1 billion, higher than Thailand and Singapore. However, if compared to the total retail trade, e-commerce sales in Indonesia only contributed 0.07 percent. That is, the Indonesian e-commerce market has the opportunity to grow bigger. Especially with the largest population and level of gross domestic product (GDP) in ASEAN. (DBS Research E-Commerce in Asia: Bracing for Digital Disruption, 2016) ${ }^{6}$. As an illustration of fintech in Indonesia based on a predominantly sector for payment transactions of more than 42 percent, both help in lending sector transactions which amount to almost 18 percent. As the following picture:

Figure 2: Profile of Fintech in Indonesia (by Sector)

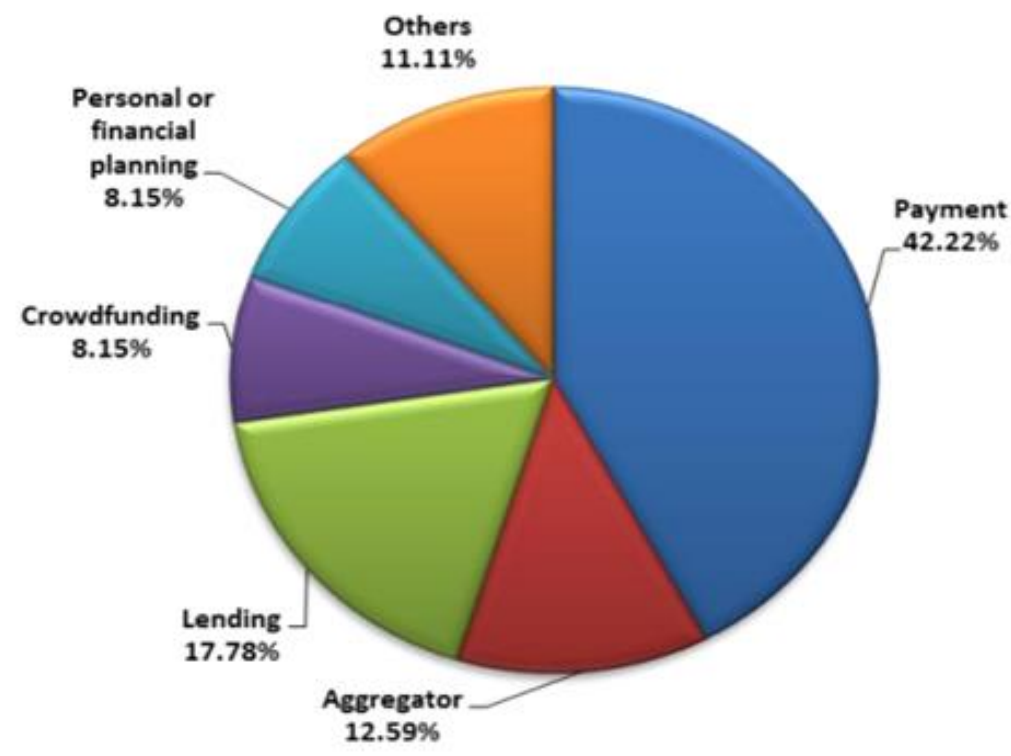

Source: Association of Fintech Indonesia, 2017

Therefore, the amount of potential that is owned by fintech needs to be given space to grow. Likewise, an adequate arrangement is needed in view of the risks that may arise. (Hadad, 2017) ${ }^{7}$. Although apparently not all fintech applications in various countries recorded success stories. In China, not all of them are successful and need to learn also from the Australian experience. Finally, Singapore authorities show how to approach

${ }^{6}$ DBS Bank. 2016. Increasing Financial Inclusion through Banking Digitalization. Downloaded on January 27, 2018 at 10.21, from https://www.dbs.com /spark/index/id_id/dbs-yes- sset/files/ (Riset\%203) \%20Increase\% 20 Financial\%20InCLUSION\%20 Through \%20 Digitality

7 Hadad D. Muliaman. 2017. Financial Technology (Fintech) in Indonesia. Financial Fervices Authority. Lecture About Fintech-IBS, 2 June 2017. Downloaded on 31 January 2018 at 3:06 p.m., from http://www.ibs.ac.id/img/doc/MDH\%20-\%20FinTech \%20IBS \%20June \%202017. Pdf 
fintech companies in the early stages of their growth (Warta Ekonomi, 2016) ${ }^{8}$. In Indonesia today many nonbank companies practice as fintech executors who channel loans to the public or SMEs, this will have the potential to lead to illegal banking practices (shadow banking). Therefore, the problem ahead is how the government makes rules that can synergize fintech with the business world, banking, SMEs and others. On the other hand encourage the role of fintech in order to increase the export of SMEs as Indonesia's mainstay sector. According to Constitution number 20 of 2008, the criteria for SMEs are classified based on the number of assets and turnover owned by a business. (Sudaryanto, 2014) ${ }^{9}$.

Table 1: Criteria for SMEs in Indonesia

\begin{tabular}{llll}
\hline No & Business & $\begin{array}{l}\text { Criteria } \\
\text { Asset (Rupiah) }\end{array}$ & Turnover (Rupiah) \\
\hline 1 & Micro Business & Max. 50 Miliion & Max. 300 Million \\
2 & Small Business & $>50$ Million -500 Million & $>300$ Million $-2,5$ Billion \\
3 & Medium Enterprises & $>500$ Million -10 Billion & $>2,5$ Billion -50 Billion \\
\hline
\end{tabular}

Note: 1 USD = 14.600 Rupiah

Source: Ministry of Cooperatives and Small and Medium Enterprises, 2013

The presence of a number of fintech companies contributed to SMEs development. Not only limited to helping finance business capital, but the role of Fintech has also penetrated into various aspects such as digital payment services and financial arrangements. Constraints in implementing fintech to improve inclusive finance SMEs in Indonesia include infrastructure, human resources, legislation and lack of financial literacy ${ }^{10}$.

\section{Methodology}

In this study a qualitative descriptive approach was used, which emphasized the discussion by examining the role of fintech to encourage the export of small and medium industries in Indonesia and Primary data used in this research through a literature study. Data sources that can be used are data from the Financial Services Authority (OJK), Bank Indonesia and various relevant data sources. According to IOSCO (2017), ${ }^{11}$ the term fintech is used to describe various innovative business models and emerging technologies that have the potential to change the financial services industry. Fintech maps eight categories, such as regarding payment activities, insurance, planning, borrowing and crowdfunding, the blockchain, trade and investment, data and analytics, and security.

\section{Results and Discussion}

One of Fintech's roles is to open up greater opportunities for household and business consumers, including small and medium-sized businesses (SMEs) to access various financial services. Likewise, Fintech offers a variety of convenience, the speed of service, and lower costs and convenience for consumers in enjoying financial services. The important implications and benefits of Fintech are financial inclusion which is

${ }^{8}$ Warta Ekonomi, 2016. If Fintech is not set, it can create Shadow Banking. Downloaded on March 1, 2018 at 10:53, from https://www.wartaekonomi.co.id/read104393/ if-unregulated-fintech-can-create-shadowbanking.html

${ }^{9}$ Sudaryanto. Ragimun. Wijayanti.R. 2013. The SMEs Empowerment Strategy Faces the ASEAN Free Market. Financial and Monetary Journal. Fiscal Policy Agency Ministry of Finance.Vol.16 / No.1 / 2013

${ }^{10}$ Irma.M. Inayah.A.R. Bella G.N. 2018. Masharif al-Syariah Journal: Journal of Economics and Sharia Banking / Vol. 3, No. 1, 2018

11 IOSCO. 2017. IOSCO Research Report on Financial Technologies (Fintech). Downloaded May 182018 at 09.14, from https://www.iosco.org/library/pubdocs/pdf/IOSCOPD554 .pdf 
expected to be able to promote sustainable economic growth and enable income diversification, especially for SMEs and can overcome various investment risks. In addition, currently technological innovations in financial services are developing very rapidly in new ways and utilizing varied business models, such as business models using big data technology, artificial intelligence (AI), machine learning, cloud computing, biometrics and etc. The role of Fintech in Indonesia is very necessary because it is expected to be able to encourage the level of community welfare, help fulfil domestic financing needs, encourage more even distribution of national financing in each province, increase national financial inclusion and can boost the ability of small and medium industrial exports. Following is the development of indicators of potential digital financial services in 33 provinces in Indonesia. The above policy is in line with inclusive financial policies. These policies include financial service deepening which targets the lower middle class. Thus, the expected financial services in Indonesia are not intended for the upper middle class only, but also for the lower middle class. Therefore, every Indonesian citizen has the right to have easy access to financial products. As a monetary regulator in Indonesia, currently Bank Indonesia has an index that aims to measure the level of financial inclusion called IIK, the Inclusive Financial Index. IIK consists of three main variables, namely access, usage and quality.

\section{Figure 3: Potential Macro Indicators of Digital Financial Services in 33 Provinces in Indonesia}

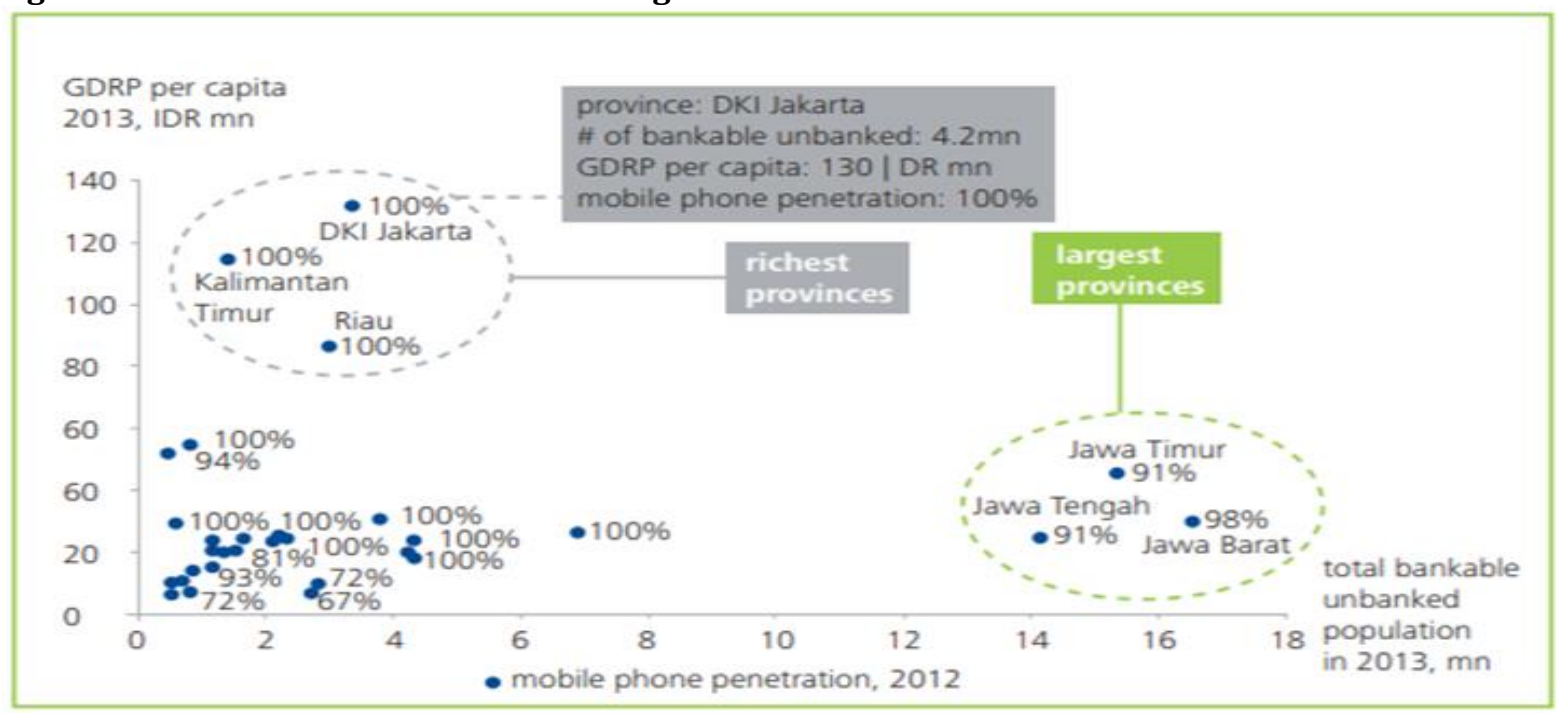

Source: OECD Economic Survey of Indonesia, 2012

Figure 3 shows that the potential of digital financial services in several provinces that are quite rich such as the Special Capital Region(Jakarta), Riau and East Kalimantan, has large regional transfers compared to other provinces is expected to drive regional economic growth. Thus there will be an increase in financial services in the region, especially for small and medium entrepreneurs. On the other hand there are three large provinces that have a bankable population to improve their digital financial services such as East Java, West Java and Central Java. Third, provinces that have relatively low Gross Regional Domestic Product (GRDP), need to be encouraged in order to improve access and financial services. Financial inclusive conditions are expected to provide benefits, among others, improving economic efficiency, supporting financial system stability, reducing shadow banking or irresponsible finance, supporting financial market deepening and providing the new market potential for banks. In addition, it is also expected that it will support the improvement of Indonesia's Human Development Index (HDI), can contribute positively to sustainable economic growth both locally and nationally and low-income trap rigidity, so as to improve the welfare of the community, which ultimately leads to a decrease in poverty. According to the financial approach, financial literacy can be interpreted as financial ability.

The Financial Services Authority as a financial services regulator had conducted a survey in 2013 to assess the level of financial literacy of the Indonesian people. The results of the survey are that the implementation of education in order to improve financial literacy in the community was very much needed. The level of financial literacy of the Indonesian population is divided into four parts, namely: Well literate (21.84\%), 
which has knowledge and beliefs about financial service institutions and financial services products, including features, benefits and risks, rights and obligations related to financial products and services, as well as having the skills to use financial products and services. Sufficient literate (75.69\%), has knowledge and beliefs about financial service institutions and financial products and services, including features, benefits and risks, rights and obligations related to financial products and services. Less literate $(2.06 \%)$, only has knowledge of financial service institutions, financial products and services.

Not literate (0.41\%), lacks knowledge and beliefs about financial services institutions and financial products and services, and lacks skills in using financial products and services. Financial literacy is an important thing that everyone should have. A person with good literacy will be able to see money from a different perspective and have control over his financial condition. The person will know what to do with the money they have and how to use it. Likewise, in institutions or institutions such as small and medium enterprises that also have to have financial literacy to advance their business. Small and medium industries which are usually creative industries generally still have difficulties accessing banking. Though banks have used fintech as one of its marketing tools. Currently there is a People's Business Credit (KUR) for the creative industry, giving KUR to the creative industry requires several things, namely: the establishment of technical guidelines for KUR distribution, and the need for socialization so that the public gets information about the KUR creative economy.

At present, KUR Ekonomi Kreatif is distributed with the same scheme as KUR in general due to the distribution of sectoral KUR with special schemes (eg specificity in terms of the grace period and payback period) which cannot be accommodated in the Coordinating Minister for Economic Affairs Regulation No. 13 of 2015. This is different from the previous Coordinating Minister for Economic Affairs Regulation, Coordinating Minister for Economic Affairs Regulation No. 8 of 2015 which allows for special sectoral KUR schemes (only regulating perennials). In Coordinating Minister for Economic Affairs Regulation No. 8 of 2015 stated that the period of KUR specifically for perennials is 10 years with the grace period agreed upon by KUR suppliers according to their characteristics, which is different from the general KUR scheme, which is 4 years for financing or working capital loans and 5 years for financing or investment credit. Another obstacle in the implementation of fintech is the difficulty of coordinating institutional arrangements for the development of technology-based SMEs, such as grant funding to start-up tech businesses constrained by State Expenditure Budget (namely APBN) regulations that currently do not allow grants.

In addition, alternative funding sourced from certain funds, for example funds for Innovative and Productive Research, the Education Fund Management Institute (namely LPDP), the Government Investment Center (namely PIP), and the utilization of the Universal Service Obligation (USO) fund of the Ministry of Communication and Informatics still require more discussion. In connection with the above, the necessary follow-up is to review other forms of funding through expenditure schemes that are in accordance with State Expenditure Budget regulations. Coordinate between ministries and agencies to get input to determine the right scheme for tech start-up funding for each funding alternative. In addition, it continues to implement fintech, especially in banking institutions that provide breakthroughs and innovations in banking services that are faster, easier, and safer so that all elements of Indonesian society can enjoy access to these services. In addition to the relatively low use of fintech for access to banking institutions, other factors that make Indonesian society still have difficulties in accessing banking services, particularly in the LOR (Leading, Outermost and Remote) areas, are the unequal access to banking services. The inequality of access to banking services is still a problem that continues to be faced by banking institutions, especially people in remote areas that cannot be reached by these banking and financial services institutions. This is also due to the condition of the people who are not yet fully familiar with banking services and other financial services, so that they have the potential to be exploited by illegal funding parties such as moneylenders (Habibi, 2016) ${ }^{12}$.

Fintech's Role in SMEs: At present a number of fintech companies have contributed to the development of SMEs, not only assisting in business capital financing but fintech also plays a role in various aspects such as digital payment services and financial arrangements. Some fintech services for SMEs, among others.

\footnotetext{
${ }^{12}$ Habibi, Y. 2016 Smart Practice Reflections. Republika. Downloaded on April 17, 2018 at 10:21, from

http://www.republika.co.id
} 
A. Capital loan: Some fintech companies provide capital loan services with a simpler submission process than conventional financial institutions such as banking. Such facilities such as not needing to surrender guarantees and only complete some document requirements, this online loan service is an alternative to conventional bank loans or other financing companies. The proposed funding will usually be disbursed in a relatively shorter period of less than a week. There are several examples of fintech companies that provide online loan services such as Modalku.co.id and Pinjam.com.

B. Digital Payment Services: Fintech companies usually also provide digital payments that are easier and safer for businesses. With an easier and safer payment process, this will be able to attract more consumers so that it will benefit businesses or SMEs. One of Fintech that provides digital payments is the Jenius application that synergizes with online transportation service companies.

C. Financial Management Services: There are several applications that offer financial management services. This innovation aims to help SME businessmen in managing corporate finances. Services provided include recording expenses, monitoring investment performance, and financial consultations at no charge. Some fintech companies that provide financial management services such as Dompetsehat.com and Ngatur duit.com. Data from the Ministry of Cooperatives and SMEs in 2017 shows that foreign exchange from SMEs is very high reaching 88.45 billion Rupiah. This figure has increased to eight times compared to 2016.

Fintech Regulation: Fintech startups will not appear much if you don't have a big role. At present many things have made the development of fintech able to influence the lifestyle of the world community including Indonesia. These reasons make fintech continue to grow into a new need for the community. Some reasons that make fintech an important area for the lifestyle and financial condition of the world community. But the regulation is not maximized (Fahlevi, 2016) ${ }^{13}$. The financial sector has an important role to support a country's economic strength. With the development of increasingly advanced technology, the financial sector also experienced a more modern and practical development. This is what drives the fintech business to grow rapidly in Indonesia. Moreover, supported by Indonesia as the 5th largest country in the world as an internet user.

Table 2: Fifteen Countries with the Highest Number of Internet User

\begin{tabular}{|c|c|c|c|c|c|c|}
\hline$\#$ & Country or Region & $\begin{array}{l}\text { Population, } \\
2018 \text { Est. }\end{array}$ & $\begin{array}{l}\text { Population } \\
2000 \text { Est. }\end{array}$ & $\begin{array}{l}\text { Internet Users } \\
\text { 31 Dec } 2017\end{array}$ & $\begin{array}{l}\text { Internet Users } \\
31 \text { Dec } 2000\end{array}$ & $\begin{array}{l}\text { Internet } \\
\text { Growth }\end{array}$ \\
\hline 1 & China & $1,415,045,928$ & $1,283,198,970$ & $772,000,000$ & $22,500,000$ & $3,331 \%$ \\
\hline 2 & India & $1,354,051,854$ & $1,053,050,912$ & $462,124,989$ & $5,000,000$ & $9,142 \%$ \\
\hline 3 & United States & $326,766,748$ & $281,982,778$ & $312,322,257$ & $95,354,000$ & $227 \%$ \\
\hline 4 & Brazil & $210,867,954$ & $175,287,587$ & $149,057,635$ & $5,000,000$ & $2,881 \%$ \\
\hline 5 & Indonesia & $266,794,980$ & $211,540,429$ & $143,260,000$ & $2,000,000$ & $7,063 \%$ \\
\hline 6 & Japan & $127,185,332$ & $127,533,934$ & $118,626,672$ & $47,080,000$ & $152 \%$ \\
\hline 7 & Russia & $143,964,709$ & $146,396,514$ & $109,552,842$ & $3,100,000$ & $3,434 \%$ \\
\hline 8 & Nigeria & $195,875,237$ & $122,352,009$ & $98,391,456$ & 200,000 & $49,095 \%$ \\
\hline 9 & Mexico & $130,759,074$ & $101,719,673$ & $85,000,000$ & $2,712,400$ & $3,033 \%$ \\
\hline 10 & Bangladesh & $166,368,149$ & $131,581,243$ & $80,483,000$ & 100,000 & $80,383 \%$ \\
\hline 11 & Germany. & $82,293,457$ & $81,487,757$ & $79,127,551$ & $24,000,000$ & $229 \%$ \\
\hline 12 & Philippines & $106,512,074$ & $77,991,569$ & $67,000,000$ & $2,000,000$ & $3,250 \%$ \\
\hline 13 & Vietnam & $96,491,146$ & $80,285,562$ & $64,000,000$ & 200,000 & $31,900 \%$ \\
\hline 14 & United Kingdom & $66,573,504$ & $58,950,848$ & $63,061,419$ & $15,400,000$ & $309 \%$ \\
\hline 15 & France & $65,233,271$ & $59,608,201$ & $60,421,689$ & $8,500,000$ & $610 \%$ \\
\hline
\end{tabular}

Source: Internet World Stats, internetworldstats.com, 2018

${ }^{13}$ Fahlevi I. Simon. 2016. The Role of Financial Technology and its Regulations in Indonesia. Journal. Downloaded on March 6, 2018 at 11:24 a.m. from https://www.jurnal.id/id/blog/peran-teknologi-finansial-sertaregulasiinya-di-Indonesia 
Current progress in several fields of fintech, including payment processing, bookkeeping process, buying and selling shares, borrowing money and others. Fintech regulations in Indonesia are still being reviewed by the Financial Services Authority (namely OJK). OJK ensures that it will oversee the business that fintech undergoes with a number of strict rules related to determine the minimum capital limit of the fintech industry. Thus this regulation will aim to protect consumers. OJK will issue regulations regarding digital financial innovation. These rules are aimed at fintech-based financial companies. While Bank Indonesia as the central bank in Indonesia has also issued Bank Indonesia Regulation number 19/12/ PB /2017 concerning the implementation of fintech. There are three main pillars for Indonesia to achieve financial inclusion through the development of the fintech industry. First, building adequate infrastructure. Secondly, creating regulations that are clearer and more targeted, and thirdly is forming stronger integration and synchronization between Fintech business players, monetary regulators, financial services and fiscal. Everything will not be achieved without positive coordination and collaboration. Some of the agenda of the Government's attention to the actors of the fintech sector include regulations on the use of electronic signatures, digital Know Your Customer (KYC) operations, data security, processing payment transactions and electronic wallets or money, as well as online loan-based legal capacity.

Other support from the government is the presence of the BI Fintech Office which was launched on November 14, 2016, which is intended as a forum for review, risk mitigation, evaluating business models and fintech products or services, as well as research initiators related to technology-based financial service activities. On the other hand, the support of traditional financial institutions can be seen from the increasing number of strategic partnerships carried out with Fintech start-up companies. Collaboration and synergy between all stakeholders (government, regulators and businesses) is the key to the strength of the financial ecosystem and is the most appropriate formula to accelerate the realization of financial inclusion for all Indonesian people including SMEs. This will enable all levels of the population to utilize more financial products and services, improve their welfare, alleviate poverty and ultimately contribute to national economic growth (Luhur, 2017) ${ }^{14}$.

Fintech Solution for Smes: In detail some of the fiscal incentives that have been available to encourage the development of SMEs in Indonesia include the provision of Tax Holiday, Tax Allowance, Restrictions on Simple House Prices Exempted from Imposition of Value Added Tax, Government Borne Income Tax for geothermal commodities and interest on returns SBN issued in international markets, reduction for motorized vehicles (hybrid and low cost green car). Likewise, facilities are not collected from Value Added Tax (VAT) and Value Added Tax on Luxury Goods on taxable goods that get an exemption from import duties, according to certain criteria, for example import of goods for upstream oil and gas exploration and geothermal exploration. This includes a reduction in some tariffs on import duties, exemptions from import duties on capital goods imports in the framework of the development and development of the electric power industry for the public interest and the provision of government borne import duties. The facility facilities will be optimal and utilized by the SMEs so it must continue to be socialized to the community and use fintech as a supporting tool.

The government has also provided various convenience facilities not only for big businessmen but also for SMEs or small and medium industries such as facilities for the Import of Export Purpose (namely KITE) for SMEs. This facility is given to export-oriented small industries in the form of exemption from import duty and Value Added Tax (VAT). The purpose of this facility is to make the Indonesian industry more efficient and the results of medium industries products can compete in the international market. The process and activity of this facility service can be done with Electronic Data Interchange (EDI) so that it is faster. It is hoped that with the advancement of fintech the service will also be improved so that it is simpler, easier and more useful for users. Referring to the goals and direction of SME empowerment policies, a strategy is needed in the macro,

\footnotetext{
${ }^{14}$ Luhur, Niki. 2017. Fintech and Its Existence: Swear or Collaberative. Indonesian Fintech Association. downloaded July 252018 from https://fintech.id/ Idea\% 20PDF/Fintech\%20Talk\%20-200pini\%20Editorial\%201\%20-Fintech\%20 Mengusik \% 20 atau \%20 Kolaboratif-\%20-\%20 Niki\%20 Luhur.pdf
} 
and micro order through the implementation of SME empowerment programs as follows: Creation of SMEs business climate.

The aim of this program is to facilitate the implementation of a business environment that is economically efficient, healthy in competition, and non-discriminatory for the survival and improvement of the performance of small and medium enterprises. Development of business support systems for SMEs. The program aims to facilitate, expedite, and expand access of SMEs to productive resources in order to be able to take advantage of open opportunities and the potential of local resources and adjust the scale of business in accordance with the demands of efficiency. Entrepreneurship development and SMEs excellence. The program is aimed at developing entrepreneurial spirit and spirit and improving the competitiveness of SMEs, so that knowledge and entrepreneurial attitudes develop and productivity increases; Small-scale Business Empowerment. The program is intended to increase the income of people engaged in economic business activities in the informal sector with micro-scale business, especially those who are still in poor families in order to obtain a fixed income, through efforts to increase business capacity, so that it becomes a more independent business unit.

Lessons Learned in Some Countries Concerning Fintech: When looking at the development of fintech in several countries such as Australia, SMEs are an important part of the economy, which constitutes 97 percent of the business and employs more than 47 percent of the workforce. The Australian Government has launched the Victoria Start-up Initiative worth AU \$ 60 million to develop and support Fintech. SMEs usually face many problems, such as with cash flow, and also the difficulty of opportunities to develop such as expansion. Fintech is a solution for both problems. Boomerang is a cash flow management and budgeting management tool, integrated with banks, credit cards and loan accounts, and types of expenses and cash flows by category, helping budget and bill payment reminders. In terms of loans for expansion, Moula is a startup that provides alternative loan platforms for SMEs in Australia. Moula provides data-based addition le. In addition, for SMEs, when businesses are not known, they do not have the reputation and need to gain the trust of potential customers. Escrow options will take advantage of customer trust, allowing them to pay as soon as they receive their goods. Generally, people who run SMEs have many roles. Thus, the adoption of technology, especially Fintech, needs to be adjusted to a simpler business process, enabling a shorter Learning Curve.

Luke Hally4 emphasizes that FinTech, in the context of SMEs, primarily revolutionizes the payment process through more smooth and user-friendly transactions, which in turn will contribute to a stronger economy. Unlike the previous section, this section of the book explains Fintech solutions from a business perspective. This explains how FinTech can be useful not only for businesses, but also for their suppliers and customers. As such, this section is a good reference for SMEs, and readers who are considering building their startups. Nding platform based on SME transaction data and company profile (Amalia, 2016) ${ }^{15}$, To anticipate the occurrence of several trade disputes and export-import activities between APEC member countries, especially those carried out by SMEs, the Online Dispute Resolution (ODR) service is being developed, which will help SMEs related to legal legal certainty, legal certainty for businesses and help to invest in the future that is more certain so as to reduce uncertainty. The development of electronic commerce today, has inspired electronic dispute resolution. In the midst of a legal system that does not keep up with the times and the rapid advances in technology has led to the idea of dispute resolution online, in the form of online arbitration (EArbitration). Online arbitration is an attractive choice in resolving E-Commerce disputes. Characteristics of transactions on the internet are cross-border geographic transactions that connect consumers with businesses from various countries including MSEs that can cause disputes. The dispute in question is a relatively small nominal value, but requires a quick settlement, and with a cost that is not too expensive. Therefore ODR is a provider of dispute resolution services, specifically for disputes online.

15 Fitri Amalia. 2016. The Fintech Book: The Financial Technology Handbook for Investors, Entrepreneurs and Visionaries. Journal of Indonesian Economy and Business Volume 31, Number 3, 2016. Gajah Mada University 
Expanding Access to Network Marketing Information for SMEs: In dealing with an increasingly open and competitive market mechanism, market control is a prerequisite for improving the competitiveness of SMEs. In order to master the market, SMEs need to get information quickly and easily, both information about the production market and the factor market. Information about the production market is needed to expand the marketing network of products produced by SMEs. Information on market production or commodity markets that are needed for example (1) what type of goods or products are needed by consumers in a particular area, (2) how is the purchasing power of the product, (3) what is the prevailing market price, (4) consumer tastes in local, regional and international markets. Thus, SMEs can anticipate various market conditions so that in carrying out its business will be more innovative.

Whereas the production factor market information is also needed especially to find out: (1) the source of raw materials needed, (2) the price of raw materials to be purchased, (3) where and how to obtain business capital, (4) where to get a workforce that professional, (5) the level of wages or salaries that are appropriate for workers, (6) where can obtain the necessary tools or machines (Effendi Ishak, 2005) ${ }^{16}$. Complete and accurate market information can be utilized by SMEs to plan their business appropriately, for example: (1) making product designs that consumers like, (2) determining prices that compete in the market, (3) knowing the market to be targeted, and many other benefits. Therefore, the role of government is very necessary in encouraging the success of SMEs in gaining access to expand their marketing network. In addition to having the ease and speed in obtaining market information, SMEs also need to have convenience and speed in communicating or promoting their businesses to consumers widely both at home and abroad.

So far, the promotion of SMEs is mostly done through joint exhibitions in limited time and place, so that the continuity of relationships and transactions with consumers cannot be guaranteed. This can be caused by long distances or lack of communication intensity. Even though the communication factor in running a business is very important, because communication will make a strong emotional bond with existing customers, it also allows the arrival of new customers. In relation to the above, the Government needs to establish communication with SMEs or by establishing SME communication centers under the Ministry of Cooperatives and Small and Medium Enterprises to provide various information, market access and others. In terms of regulators the need for caution regarding the mushrooming of Fintech companies. The Investment Alert Task Force found 227 fintech companies peer to peer (P2P) lending that did not have permission from the Financial Services Authority (OJK) as the regulator. Nearly half of that amount is illegal fintech originating from China which is proven to violate Financial Services Authority Regulation Number 77 / P0JK.01 / 2016, that each lending organizer is obliged to submit registration and permission from OJK. The Chinese company is interested in targeting the Indonesian market, because the potential for online lending and borrowing in Indonesia continues to grow, on the other hand, regulators in China continue to tighten (Cash, 2018) ${ }^{17}$.

Fintech Helps SMEs Increase Export Activities: There are several ways Fintech encourages SMEs to increase export activities, which include the following: Fintech as a loan platform provider Fintech provides very easy access for borrowers to SMEs. One of them is making loans online. Thus, SME owners only need to include the documents needed online. Lending can be assessed from various aspects, not only relying on business credit value and the background of the business owner. So that the approval process takes only a few days or hours. Fintech makes everything done online in the past, when we wanted to use a credit card, we needed an account from the owner and also an expensive credit card machine. At the moment, everything is easy with online purchases. Even PayPal-type companies have made payments online, bills, credit and employee payroll. This makes it easy for businesses to make transfers easily without having to have an

${ }^{16}$ Effendi Ishak. 2005. Article: Role of Information for SME Progress. People's Sovereignty. Yogyakarta

17 Cash. 2018. OJK: Many Fintech from China operate without permission in Indonesia. Cash newspaper. Downloaded 30 July 2018 at 08.35 , from http://keuangan.kontan.co.id/news/ojk-banyak-fintech-asal-chinaberoperasi-tanpa-izin-di-indonesia 
account. Even all can be done via mobile phones, including SMEs can make sales and payment offers using applications from smartphones. Fintech makes mass payments easier Fintech facilitates an extensive advertising network and internet-based businesses, partners and affiliates as its flagship.

Instead, these companies require mass payments. This can be a complicated process because these companies are generally spread abroad, so they must adapt to all regulations and bureaucracy in these countries. With fintech, this can be done easily, without any hassle. Payment is also made with guaranteed security, using the same rules as the bank, even with anti-terrorist rules. Fintech makes it easy to check payments for SMEs, maintaining the financial process can be complicated and time-consuming. With fintech, the entire process will be done online. So, with a matter of minutes, SMEs can manage all financial processes in a transparent and effective manner. Even in some cases, customers also benefit from an online process. This is a win-win solution for customers and businesses. Fintech makes payment bills easier SMEs find it difficult to arrange bill payments every month or every year. Business owners may delay payments until the due date to facilitate cash operations, but at the same time, late payments will adversely affect the reputation of the company and subsequent payment activities. Fintech will assist these processes. They help in arrangements to pay bills on time. Bill payments can be made online and you don't have to bother using check and envelopes or look for stamps. As an SME, fintech service providers can be a savior in terms of finance, payments and other financial services.

\section{Conclusion and Recommendations}

Fintech has an important role in helping the financial literacy of Indonesian people including SMEs. Several obstacles to the dissemination of the role of fintech continue to be overcome through a variety of ways including infrastructure improvements, socialization and financial literacy to SMEs and the creation of fintech regulatory policies that can encourage increased exports. Fintech has a relatively good level of effectiveness to improve the quality of financial and banking system services in Indonesia. The implementation of fintech in Indonesia is still relatively new and studies, socialization and literacy are still needed that are relevant to financial technology. Need to follow-up efforts from the government, 0JK, banking practitioners, as well as financial technology service providers to conduct a more in-depth study, socialization and financial literacy. Therefore, banking institutions and financial technology service providers need to collaborate and coordinate with various institutions, including the government, central bank (Bank Indonesia) and 0JK. Likewise, the government needs to make clear and aligned rules to foster and avoid the risk of the financial services industry. The government can also establish a communication center for SMEs to provide information and market access and other events. This is crucial because the development of fintech in Indonesia is very fast.

\section{References}

Akbar, D. S. \& Fadillah. (2016). Crowdfunding Concept for Infrastructure Funding in Indonesia. Ministry of Finance.

Cash. (2018). OJK: Many Fintech from China operate without permission in Indonesia. Cash newspaper.

Chrismastianto, A. W. \& Immanuel. (1997). SWOT Analysis of Financial Technology Implementation on the Quality of Banking Services in Indonesia. Jurnal Bisnis Indonesia, 20, I.

DBS Bank. (2016). Increasing Financial Inclusion through Banking Digitalization.

Deloitte. (2015). Digital Financial Services in Indonesia.

Desai, Falguni. (2015). The Evolution of Fintech.

Effendi Ishak. (2005). Article: Role of Information for SME Progress. People's Sovereignty. Yogyakarta

Fahlevi, I. \& Simon. (2016). The Role of Financial Technology and its Regulations in Indonesia, Journal.

Fitri Amalia. (2016). The Fintech Book: The Financial Technology Handbook for Investors, Entrepreneurs and Visionaries. Journal of Indonesian Economy and Business, 31, 3.

Habibi, Y. (2016). Smart Practice Reflections. Republika.

Hadad, D. \& Muliaman. (2017). Financial Technology (Fintech) in Indonesia. Financial Fervices Authority. Lecture About Fintech-IBS, 2 June 2017.

Irma. M., Inayah. A. R. \& Bella, G. N. (2018). Masharif al-Syariah Journal: Journal of Economics and Sharia Banking, 3, 1. 


\section{Journal of Social and Development Sciences (ISSN 2221-1152)}

Vol. 9, No. 3, pp. 66-77, September 2018

IOSCO (2017). IOSCO Research Report on Financial Technologies (Fintech).

Julianto, P. A. (2016). Fintech, the way in which banking meets the needs of customers. Compass.

Luhur, Niki. (2017). Fintech and Its Existence: Swear or Collaborative. Indonesian Fintech Association.

Sudaryanto Ragimun Wijayanti, R. (2013). The UMKM Empowerment Strategy Faces the ASEAN Free Market. Financial and Monetary Journal. Fiscal Policy Agency Kemenkeu, 16, 1.

Warta Ekonomi. (2016). If Fintech is not set, it can create Shadow Banking.

Wulan, V. \& Rakhma. (2017). Financial Technology (Fintech) a New transaction in Future. Journal of Electrical Engineering and Computer Sciences, 2, 1. 